\title{
Association between oral malodor and adult periodontitis: a review
}

\author{
Manabu Morita ${ }^{\text {** }}$ \\ and Hom-Lay Wang ${ }^{2}$ \\ ${ }^{1}$ Department of Preventive Dentistry, \\ Hokkaido University Dental School, Sapporo, \\ Japan; ${ }^{2}$ Department of Periodontics/ \\ Prevention/Geriatrics, University of Michigan \\ School of Dentistry, Ann Arbor, MI, USA
}

\author{
Morita M, Wang H-L: Association between oral malodor and adult periodontitis: \\ a review. J Clin Periodontol 2001; 28: 813-819. (C) Munksgaard, 2001.
}

\begin{abstract}
Background: Bad breath has a significant impact on our daily social life to those who suffer from it. The majority of bad breath originates within the oral cavity. However, it is also possible that it can come from other sources such as gastricintestine imbalance. The term "oral malodor" is used to describe a foul or offensive odor emanating from the oral cavity, in which proteolysis, metabolic products of the desquamating cell, and bacterial putrefaction are involved. Recent evidence has demonstrated a link between oral malodor and adult periodontitis. The process of developing bad breath is similar to that noted in the progression of gingivitis/ periodontitis. Oral malodor is mainly attributed to volatile sulfur compounds (VSC) such as hydrogen sulfide, methyl mercaptan and dimethyl sulfide. The primary causative microbes are gram-negative, anaerobic bacteria that are similar to the bacteria causing periodontitis. These bacteria produce the VSC by metabolizing different cells/tissues (i.e., epithelial cells, leukocytes, etc.) located in saliva, dental plaque, and gingival crevicular fluid. Tongue surface is composed of blood components, nutrients, large amounts of desquamated epithelial cells and bacteria, suggesting that it has the proteolytic and putrefactive capacity to produce VSC. One of the challenges in dealing with oral malodor is to identify a reliable test for detecting bad breath.

Aims: The purposes of this review article were: (1) to correlate the relationship between oral malodor and adult periodontitis; (2) to analyze current malodor tests and discuss available treatment regimens.
\end{abstract}

Key words: oral malodor/periodontal disease; oral malodor/etiology and treatment; halitosis/ pathogenesis; sulfur compounds/toxicity

Accepted for publication 4 September 2000
Halitosis affects a large proportion of population and may cause a significant social or psychological handicap to those suffering from it (Hine 1957). This common disease has been ignored for too long by periodontologists, even though the most common cause is related to microbiota of the subgingival areas and the related tongue coating (Van Steenberghe 1997). It is estimated that more than $50 \%$ of population in North America suffer from halitosis (Tessier \& Kulkarni 1991, Bosy 1997). An epidemiological survey of the gen-

\footnotetext{
* Previously, Department of Preventive Dentistry, Okayama University Dental School, Okayama, Japan.
}

eral population of Japan showed that $24 \%$ of the individuals examined complained about bad breath (Miyazaki et al. 1995a). Consequently, halitosis is one of the major sources of multimillion-dollar industry. In the USA alone, over $\$ 500$ million are spent annually on mouthwashes, sprays, and related overthe-counter products toward to management of this common problem (Tessier \& Kulkarni 1991).

Halitosis is the general term used to describe unpleasant breath, regardless of its sources, oral or non-oral. For example, the air expired through the nose is involved in halitosis. Oral malodor is the term especially used to describe the odor from the oral cavity (Kleinberg \&
Westbay 1990, Newman 1996). Delanghe et al. (1997, 1999) examined hundreds of patients with bad breath and found that around $87 \%$ of them were originated by oral causes, whereas only 5-8\% were attributed to ear-noseand-throat (ENT) causes.

There are various compounds that produce unpleasant smelling in human oral environment, such as hydrogen sulfide, methanethiol, dimethylsulfide, ndodecanol, n-tetradecanol, phenol, indole, diphenylamine, pyridine and others. (Kostelc et al. 1980, 1984). Especially, volatile sulfur compounds (VSC; hydrogen sulfide, methyl mercaptan and dimethyl sulfide), that arise from bacterial metabolism of amino 
acids, mainly contribute to oral malodor (Tonzetich \& Richter 1964, Tonzetich 1971). It has been demonstrated that the intensity of clinical bad breath is significantly associated with amount of intra-oral VSC level (Rosenberg et al. 1991a, b). The periodontal pocket is an ideal environment for VSC production with respect to the bacterial profile and sulfur source. In addition, VSC also accelerate periodontal tissue destruction. This may explain why patients with periodontal diseases often complain of oral malodor.

Therefore, the purposes of this review article were: (1) to correlate the relationship between oral malodor and adult periodontitis; (2) to analyze current malodor tests and discuss available treatment regimens.

\section{Clinical Relationship between Periodontal Disease and Oral Malodor}

Studies conducted over the past 50 years have shown the link between periodontal disease and offensive odor. For example, saliva collected from individuals with periodontal disease putrefied more rapidly than that from healthy individuals (Sulser et al. 1939, Berg et al. 1946, 1947). Berg et al. (1947) collected saliva of 100 periodontally healthy and 100 periodontally involved patients. After 3-h incubation at $37^{\circ} \mathrm{C}$, saliva of periodontitis patients showed higher amount of hydrolysis, indole and sulfide than that from healthy patients. Consequently, a more disagreeable odor was produced from the saliva of periodontitis individuals. VSC in mouth air increased with the increase of the number and depth of periodontal pockets (>3 mm) (Tonzetich 1978). Later, Yaegaki \& Sanada (1992a, b) also found similar results, in which the concentrations of hydrogen sulfide and methyl mercaptan in mouth air were higher in patients with probing depth $>4 \mathrm{~mm}$ than healthy controls. They also found that the methyl mercaptan/hydrogen sulfide ratios were significantly increased in patients with periodontal disease and indicated the possible role of methyl mercaptan as an accelerator for periodontal disease.

Several clinical studies demonstrated the elevated VSC levels in periodontally involved pockets. Rizzo (1967) measured hydrogen sulfide production in periodontal pockets semi-quantitatively. He used filter paper strips impreg- nated with lead acetate. A positive reaction occurred when the paper turned black or brown after insertion into periodontal pockets. A positive correlation was noted between the amounts of hydrogen sulfide in the gingival crevice and the depth of corresponding periodontal pockets. Soils-Gaffer et al. (1980) measured hydrogen sulfide production in 240 gingival crevicular fluid (GCF) samples. A positive correlation was observed between gingival index, GCF volume and hydrogen sulfide production. Coil \& Tonzetich (1992) analyzed VSC in 20 periodontal pockets from 17 periodontal patients. The inflamed pockets (with bleeding on probing) exhibited significantly higher total sulfide than corresponding non-inflamed pockets (without bleeding on probing). Recently, we measured VSC in 210 periodontal pockets with different radiographic bone loss from 70 periodontal patients (Morita \& Wang 2001a, b). The result demonstrated that VSC rose significantly with an increase in radiographic bone loss, and were highly correlated with other clinical parameters such as probing pocket depth, clinical attachment level, and bleeding on probing.

\section{VSC Production through Periodontal Pathogens}

VSC is produced through the result of putrefaction of food debris, cells, saliva, and blood within the oral cavity, mainly through microbial putrefaction (Kleinberg \& Westbay 1990, Ratcliff \& Johnson 1999). Oral microbes, especially gram-negative bacteria, are primary pathogens responsible for oral malodor production (McNamara et al. 1972, Tonzetich \& McBride 1981, Persson et al. 1990). McNamara et al. (1972) incubated bacterial-free saliva filtrate alone or with broth medium and detected no malodor. On the other hand, when they changed the conditions to the bacterialcontaining saliva, malodor was produced. In addition, the ratio of grampositive to gram-negative organisms in saliva underwent a shift in favor of growth of gram-negative organisms, accompanied by appearance of putrid odor. Tonzetich \& McBride (1981) found the pathogenic, proteolytic strains of Bacteroides melaninogenicus produced more VSC than non-proteolytic strains. Treponema denticola, Porphyromonas gingivalis, Porphyromonas endodontalis, Prevotella intermedius, and Bacteroides loescheii produced significantly higher amount of sulfides than other bacteria (Persson et al. 1990). Other bacterial species recovered from periodontal pockets such as Enterobacteriaceae, Bacteroides forsythus, Centipeda periodontii, Eikenella corrodens, Fusobacterium periodonticum, etc. also had a high capability to generate VSC in vitro (Persson et al. 1990, Goldberg et al. 1997).

Reduced salivary flow rate and stagnation of saliva were found to contribute to bacterial shift and oral malodor formation (Kleinberg \& Westbay 1990). In addition, saliva in a slightly alkaline condition produces typical odor, while slightly acid saliva has the opposite effect (McNamara et al. 1972). An acid $\mathrm{pH}$ prevents the formation of odorous metabolic end products by inactivating the enzymes required for the putrefaction of amino acids (McNamara et al. 1972), and several amino acids favors alkalinity when the $\mathrm{pH}$ is acidic (Kleinberg \& Codipilly, 1995). Oxygen depletion in saliva/plaque also plays a complex but important role in malodor formation. Oxygen depletion is a significant factor in determining the extent to which the oxidation-reduction potential $\left(E_{\mathrm{h}}\right)$ falls during amino acid degradation. This is an important way to determine which kinds of bacteria can grow and whether oral putrefaction and malodor may occur (Kleinberg et al. 1996). Therefore, oxygen depletion and its availability may control the types of odoriferous compounds.

The mechanism of how microbes influence sulfide formation is described by the following example. Fusobacterium nucleatum, a prominent organism in gingivitis and periodontitis (Slots 1977), metabolizes cysteine and methionine to produce VSC (Pianotti et al. 1986). The desulfuration of cysteine is initiated by cysteine desulfhydrase, where pyruvate, ammonia, and hydrogen sulfide are generated. The hydrolysis products of methionine are $\alpha$-ketobutyrate, ammonia, and methyl mercaptan. The metabolic pathways involved in methionine and cysteine degradation during odor formation are also well documented by Kleinberg \& Westbay (1990).

It is, of course, recognized that not all malodors emanating from the mouth are caused by microorganisms (McNamara et al. 1972). In periodontally healthy or edentulous indi- 
viduals with no detectable dental causes, oral malodor production may be associated with degradation of proteins, sulfur containing organic compounds on the surface of the tongue, tonsils and in the saliva. Many patients with a healthy oral status have oral malodor caused by expired air passing over sulfur and protein rich secretions associated with post-nasal drip (Newman 1996).

\section{Sulfur Source in Oral Cavity}

Tonzetich \& Kestenbaum (1969) incubated whole saliva, salivary sediment and supernatant obtained from the centrifugation of whole saliva to compare their ability in producing malodor. The results indicated that whole saliva produced the maximal odor. The sediment by itself, which contained exfoliated squamous cells, could also produce malodor. However, the supernatant alone did not generate any odor. Later, Tonzetich \& Johnson (1977) analyzed thiol, disulfide, total sulfur and inorganic sulfate in whole saliva, its supernatant and sediment fractions. Findings from this study demonstrated a direct correlation between VSC production and its thiol and disulfide content. The sonication of whole saliva significantly increased thiol and disulfide concentration of the supernatant. This corresponded with the decreased concentration in sediment. Results from these two studies suggest that cellular components in salivary sediment are essential for odor production. The disulfide present in salivary sediment is mostly cystine. Cystine can be converted into cysteine that produces malodor when saliva is incubated for a period of time (Kleinberg \& Westbay 1990). On the contrary, fresh saliva does not have significant potential for producing malodor, since it has a low level of free amino acids (Kleinberg \& Westbay 1990).

Plaque, like the salivary sediment, possesses strong potential for odor formation (Tonzetich \& Kestenbaum 1969). Most of odors released were hydrogen sulfide and methyl mercaptan as that noted with salivary sediments. Plaque is composed of bacteria as well as salivary proteins. The loose outermost layer of plaque often referred to as material alba and usually contains desquamated epithelial cells and some blood cell elements (Mandel 1966). Gingival crevicular fluid also contains various sulfur sources, for example, blood cells and sulcular epithelium (Yaegaki \& Sanada 1992b).

\section{Effect of VSC in Periodontal Disease}

Hydrogen sulfide and methyl mercaptan, two major VSC associated with oral malodor, play an important role in the pathogenesis of periodontal disease. When a porcine non-keratinized sublingual mucosa was exposed to hydrogen sulfide and methyl mercaptan, its permeability increases by $75 \%$ and $103 \%$, respectively $(\mathrm{Ng} \&$ Tonzetich 1984). Bacterial antigens such as lipopolysaccharide (LPS) induce gingival inflammation, however, mere exposure to these antigens is not sufficient enough to cause gingivitis (Offenbacher 1996). Rizzo (1970) reported that preexisting agent is required to allow LPS to penetrate healthy gingival epithelium. Therefore, VSC potentially facilitate the penetration of LPS and result in inflammation (Ratcliff \& Johnson 1999).

VSC can also induce periodontal tissue destruction through variable pathways directly or indirectly. When porcine epithelial tissues were treated with methyl mercaptan, the tissues demonstrated extensive impaired and dead cells (Johnson et al. 1992a). These findings suggest that VSC are directly toxic to epithelial tissues and can facilitate bacterial invasion into underlying connective tissue. In addition, when human gingival fibroblasts were exposed to hydrogen sulfide and methyl mercaptan, total protein synthesis was reduced by $18 \%$ and $35 \%$, respectively. The changes in total protein were accompanied by a corresponding decrease in collagenous protein, which resulted from increased degradation and suppressed synthesis (Johnson et al. 1992b). Johnson et al. (1992a) reported that methyl mercaptan suppressed DNA synthesis by $44 \%$ and altered collagen metabolism in fibroblast cultures. In addition, methyl mercaptan reduces collagen synthesis by $39 \%$, while increases intracellular degradation of newly synthesized collagen by $62 \%$ (Johnson et al. 1996). Methyl mercaptan, when used alone or in combination with interleukin-1 (IL-1) or lipopolysaccharide, can significantly enhance human gingival fibroblasts to secret prostaglandin $E_{2}, \mathrm{cAMP}$ and procollagenase. These secreted substances may contribute to the increased production of collagenase and tissue destruc- tion in periodontal disease (Ratkay et al. 1995). Claesson et al. (1989) reported that polymorphonuclear leukocytes $(\mathrm{PMN})$ were able to kill bacteria even in the presence of sulfide. However, sulfides may annihilate the opsonization of $\mathrm{C} 3$ bi and affect its ability to fight bacteria (Granlund-Edstedt et al. 1991).

Methyl mercaptan and hydrogen sulfide react on proteins through the inherent activity of thiol (-SH) group. Both components bind to Type I collagen via sulfur and affect its normal function. In addition, methyl mercaptan can act as an alkalyating agent (Johnson et al. 1992b). Therefore, methyl mercaptan may be more harmful when compared to hydrogen sulfide. This is in agreement with clinical studies that demonstrated the methyl mercaptan/hydrogen sulfide ratio increased with the severity of periodontal disease (Coil \& Tonzetich 1992, Yaegaki \& Sanada 1992a, b).

\section{Tongue Coating and Oral Malodor}

While adult periodontitis is associated with oral malodor, there is also considerable evidence that even periodontally healthy individuals can exhibit significant levels of mouth odor. Areas where food is trapped and stagnated have potential to generate oral malodor. Recently, the dorsal surface of the tongue has been identified as the primary source of oral malodor in both periodontally diseased and healthy individuals (Bosy et al. 1994, De Boever \& Loesche 1995). It is interesting to note that oral malodor is more strongly associated with tongue coating rather than the severity of periodontal disease. This is attributed to a large surface area of the tongue and its papillary structure which retain considerable amounts of desquamated epithelial cells and dead leukocytes. This evidence supports the concept that microbial accumulation often contributes to malodor production (Loesche \& De Boever 1995). The microbes identified around tongue coatings are almost the same as those found in subgingival plaque (Van Winkelhoff et al. 1986).

It is generally observed that patients with chronic periodontitis have more tongue coating than healthy individuals. Yaegaki \& Sanada (1992a, b) collected the tongue coating with a tongue scraper from patients with and without 
periodontal disease, and measured the wet weight. They found that the periodontal patients had greater tongue coating than healthy controls. They also reported that VSC production by the periodontal patients' tongue coating was $4 \times$ higher than that of the controls. Miyazaki et al. (1995b) evaluated oral malodor using a portable sulfide monitor in 2,672 individuals. A high correlation was observed between VSC and tongue coating volume in all age groups, and between VSC and periodontal disease progression in the 45 to 64 year-old age group. Based on these results, they proposed that oral malodor might be caused mainly by tongue coating in the younger individuals, while both periodontal disease and tongue coating are primary sources for older individuals.

The role of specific bacteria on the tongue surface in malodor production has not been fully understood in vivo. $P$. gingivalis, $T$. denticola, and $B$. forsythus are active hydrogen sulfide producers in vitro (Persson et al. 1990). These bacteria are detectable through their ability to hydrolyze the synthetic trypsin substrate N-benzoyl-DL-arginine-2-naphthylamide (BANA test; Loesche et al. 1990, Loesche et al. 1992). De Boever \& Loesche (1995) reported VSC levels in mouth air were significantly associated with BANA score on the tongue. On the contrary, Kozlovsky et al. (1994) showed poor association between BANA scores and VSC. They evaluated the oral malodor and BANA scores in various intraoral locations (tongue, saliva and subgingival plaque) of 52 Israeli subjects. When multiple regression analysis was performed with organoleptic malodor rating as the dependent variable, both VSC in mouth air and BANA score were identified as highly associated contributing factors. One of the reasons for the poor association is that the BANA positive-bacteria might be associated with the non-sulfide odorants such as cadaverine (Goldberg et al. 1994), tetradecanol, pyridine, and phenol (Kostelc et al. 1980, 1984) that can not be detected by VSC monitor. In addition, when the BANA test was examined in relation to gingival inflammation, the BANA test exhibited low specificity and the high incidence of false positive (Loesche et al. 1992, 1997). Therefore, it is possible that even the patients with low VSC level showed the positive BANA test result.

\section{Other Oral Diseases Associated with} Oral Malodor

Specific diseases such as acute necrotizing ulcerative gingivitis and pericoronitis can also induce a distinctive malodor associated with certain pathogenic gram-negative organisms. In addition, other oral conditions associated with oral malodor include aphthous ulcers, dental abscesses, candidiasis, oral cancers, and xerostomia (Messadi 1997). Caries by itself is not an etiologic factor of malodor, unless the lesions are large enough to trap food (Rosenberg 1996).

\section{Non-oral Diseases Associated with Oral Malodor}

Hunger and morning breath are causes of temporary malodor. This is the result of stagnation of epithelial and food debris. Certain hormonal changes that occur during ovulation, menstruation, pregnancy and menopause produce malodor (Bosy et al. 1997). Other extraoral diseases such as chronic sinusitis, tonsillitis, bronchitis, diabetes mellitus, hepatic failure, renal failure, lung carcinoma, and trimethylaminuria are capable of producing oral malodor (Messadi 1997). Furthermore, some sensitive individuals may suffer from halitophobia, an imaginary bad breath (Hawkins 1987, Rosenberg 1996).

\section{Treatment and Management of Oral Malodor}

Treatment algorithm for oral malodor is a step-by-step problem-solving procedure and well described by Newman (1996). Before commencing treatment, a clinician must determine the source of malodor. The simplest way to distinguish oral from non-oral origin is to compare the smell from mouth and nose (Rosenberg 1996). If the origin is from nasal or if the patients have the potential medical etiology, they must be referred to a physician for further evaluation and treatment.

The odor generating from the mouth often requires a dental treatment. There are no standard and accepted protocols for the treatment of oral malodor, however, the possible protocols contain the basic elements including standard dental and periodontal treatment and focused oral malodor treatment. If the patient does not respond, the diagnosis cycle must be restarted (Newman 1996). Objective measurement of VSC using an instrument is an essential part of diagnosis.

Effective methods for treating malodor reduce anaerobes by improving oral hygiene and periodontal health through basic dental care (Morris \& Read 1949, Tonzetich \& Ng 1976). Individuals who flossed daily had significantly less odor level than those who did not (Rosenberg 1996). Hence, it is a good motivation tool to have patient smell the floss after each use. For patients with complicating factors such as fixed and/or removal prosthesis or for aged people, more advanced hygiene method should be employed including oral irrigation and sonic or ultrasonic toothbrush (Newman 1996).

When the patients' conventional hygiene is adequate but their oral malodor problem exist, tongue brushing is also an effective way (Rosenberg \& Leib 1995). Tonzetich \& Ng (1976) reported that tongue brushing is twice as effective as tooth brushing in reducing oral malodor. Cleaning the tongue can be performed by a toothbrush or variety of tongue scrapers that minimize gagging reflex. The patients should be reminded that the posterior part of the tongue is the least accessible but usually smells worst (Rosenberg 1996). After dental and tongue cleaning, hydrogen sulfide and methyl mercaptan concentration in the mouth air decreased by 25 to $75 \%$ (Tonzetich 1977,1978 ).

If the patients still suffer from oral malodor after maintaining good oral hygiene, rinsing or gargling with an effective mouthwash may be advised. One way to treat periodontal patients with oral malodor is a combination of regular periodontal treatment and a chlorhexidine mouth rinse (Bosy et al. 1994, Scully et al. 1994, Quirynen et al. 1998). Quirynen et al. (1998) monitored patients with oral malodor. Individuals were treated with scaling and root planing, and then divided into 2 groups, no additional treatment (a control group) and adjunctive chlorhexidine disinfection including mouth rinse, spray and subgingival irrigation (a test group). Both groups resulted in significant reductions in organoleptic odor rating. However, the test group had more obvious malodor reduction than the control group did. Although the efficacy of chlorhexidine mouth rinse has been approved, many patients do not comply with the long-term use of chlorhexidine because of alterations in taste sensations, burning sensations, and stain- 
ing to the teeth. Hydrogen peroxide mouthwashes also reduce concentration of salivary thiols. These agents may be useful in management of acute necrotizing ulcerative gingivitis (Scully et al. 1994). Various products such as a 2phase, oil-water mouth rinse (Kozlovsky et al. 1996, Yaegaki \& Sanada, 1992c), zinc chloride rinses (Tonzetich, 1978), and cetylpyridinium chloride rinse (Niles \& Gaffar 1995) can effectively reduce oral malodor for several hours. However, their long-term effect remains to be determined.

Most commercial products claim to effectively eliminate mouth odor. However, they only mask oral malodor by the use of strongly flavored solutions in an alcohol base, therefore often act as a temporary relief rather than a permanent cure (Bosy 1997). These mouthwashes may actually accelerate oral malodor because of the drying effect caused by the high alcohol content. Patients should be instructed to stop using any mouth rinses containing alcohol as part of the treatment plan to eliminate oral malodor (Rosenberg 1996).

\section{Diagnose of Oral Malodor}

Future study needs to develop more reliable and reproducible instrument for evaluating oral malodor. Subjects complaining of bad breath were generally incapable of scoring their own oral malodor in an objective fashion, and partial objectivity could be obtained if they smelled their own expectorated saliva (Rosenberg et al. 1995). So far, subjective organoleptic examination (Rosenberg et al. 1991a, Bosy et al. 1994, Iwakura et al. 1994) has been used as a benchmark for oral malodor measurement. However, there is considerable variation between judges on the ranking of the same sample (Rosenberg et al. 1991b, Rosenberg \& McCulloch 1992). In order to assess oral malodor objectively, a gas chromatography (Tonzetich 1971, SolisGaffar et al. 1975, 1980, Tonzetich et al. 1991) or a portable industrial monitor has been developed (Rosenberg et al. 1991a, b, Shimura et al. 1996). Because a gas chromatography requires technical expertise and a portable monitor can detect only VSC level, both of them are insufficient for evaluating oral malodor accurately. Bosy (1997) recommended the direct sniffing of expelled mouth air as the most reliable and simple approach to analyze oral malodor. The new diagnostic method(s) should allow us to de- termine all the possible odorous compounds separately in a short time, and hopefully, with e-commerce technology, do certain "on-line" breath analysis soon (Rosenberg 1996).

\section{Future Aspects}

VSC in periodontal pockets might be used as a predictor of periodontal disease. Periodontal disease progresses in an unpredictable fashion, with active disease followed by periods of remission or quiescence (Socransky et al. 1984). Hence, it is important for clinicians to accurately assess the following information: (a) determination of active disease sites; (b) quantitative monitoring of therapy response; and (c) prediction of the future disease sites. However, current available tools/tests are not applicable for achieving these goals due to lack of accuracy, objectivity and limited ability in diagnosing ongoing or active disease (Armitage 1996). Fine \& Mandel (1986) proposed to utilize hydrogen sulfide, one of causative periodontal pathogens' products as an indicator for disease severity. The value of this hypothesis remains to be elucidated. It is also interesting to determine the degree of contribution by pocket VSC to whole mouth odor. For this study, we have to measure VSC level in periodontal pockets quantitatively. Then multifactor analysis including pocket VSC level and odor level of the tongue and the other parts of oral cavity will provide us useuful information in management of patients with oral malodor.

The dental research community has long ignored the subject of oral malodor (Kleinberg \& Westbay 1990, Van Steenberghe 1997). Recently, along with the growing public and media interest in oral malodor, dental professionals are becoming more aware of their patients concern/needs. It is our hope that future studies will overcome the difficulty of diagnosing this long standing problem and provide effective treatments to relieve individuals who suffer from oral malodor.

\section{Zusammenfassung}

Assoziation zwischen Mundgeruch und Erwachsenenpardodontitis: Eine Literaturübersicht

Für die Personen, die darunter leiden hat schlechter Atem eine signifikante Auswirkung auf das tägliche Sozialleben. Bei der Mehrheit liegt die Ursache für schlechten Atem innerhalb der Mundhöhle. Es ist je- doch auch möglich, dass die Ursache auch aus anderen Quellen kommen kann, wie gastrointestinale Veränderungen. Der Terminus "Mundgeruch" wird verwendet, um einen fauligen oder störenden Geruch, der aus der Mundhöhle strömt zu beschreiben. Hierbei sind Proteolyse, metabolische Produkte von desquamierten Zellen und die bakteriellen Putrifikation involviert. Vor Kurzem könnte eine Verbindung zwischen Mundgeruch und Erwachsenenparodontitis aufgezeigt werden. Der Prozess der Entstehung von schlechtem Atem ist vergleichbar mit der Entstehung einer Progression von Gingivitis/Parodontitis. Der Mundgeruch wird hauptsächlich den flüchtigen Schwefelkomponenten (VSC), Methylmerkaptan und Dimethyl-Sulfid zugeschrieben. Die primär verursachenden Mikroben sind Gram-negative, anaerobe Bakterien, die ähnlich sind, wie die Bakterien, die Parodontitis verursachen. Diese Bakterien produzieren die VSC durch das Metabolisieren von verschiedenen Zellen/Geweben (z.B. Epithelzellen, Leukozyten usw.), die im Speichel, der Zahnplaque und dem Sulkusfluid vorhanden sind. Die Zungenoberfläche besitzt Blutkomponenten, Nahrungsstoffe, groBe Mengen von desquamierten Epithelzellen und Bakterien und es lässt sich annehmen, dass sie die proteolytische und putrefaktive Kapazität zum Produktion von VSC hat. Eine der Herausforderungen im Umgang mit Mundgeruch ist die Identifikation eines zuverlässigen Tests zum Nachweis von schlechtem Atem. Daher war der Zeck dieser Literaturübersicht: 1. Die Korrelation der Beziehung zwischen Mundgeruch und Erwachsenenparodontitis und 2. Die Analyse der aktuellen Mundgeruchstests, sowie die Diskussion der vorhandenen therapeutischen Vorgehensweisen.

\section{Résumé}

Association entre halitose et parodontite de l'adulte: une revue

L'halitose a un impact significatif sur notre vie sociale quotidienne. La plupart des halitoses proviennent de la cavité buccale. Cependant, il est également possible qu'elles proviennent d'autres sources telle que la mauvaise balance gastro-intestinale. Le terme halitose est utilisé pour décrire une mauvaise odeur provenant de la cavité buccale dans laquelle la protéolyse, les produits métaboliques des cellules desquamées et la putréfaction bactérienne sont impliqués. Une évidence récente a démontrée un lien entre l'halitose et la maladie parodontale. Le processus de développement d'une halitose est semblable à celui noté dans la progression de la gingivite ou de la parodontite. L'halitose est essentiellement attribuée à des composés de sulfure volatile (VSC) comme le sulfide d'hydrogène, le mercaptan méthyle et le sulfide de diméthyle. Les microbes principalement en cause sont des bactéries anaérobie Gram-négatif qui sont semblables à celles provoquant la parodontite. Ces bactéries produisent des VSC en métabolisant différentes cellules et 
tissus (c.-à-d. les cellules épithéliales, leukocytes, etc.) localisées dans la saliva, la plaque dentaire et le fluide créviculaire. La surface de la langue est recouverte d'éléments sanguins, de nourriture et de grandes quantités de cellules éphitéliales desquamées et de bactéries ayant la capacité protéolytique et putréfactive de produire des VSC. Un des défis dans le combat contre l'halitose est de trouver un test capable de détecter cette mauvaise odeur. C'est pourquoi les buts de cette revue ont été: (1) de corréler la relation entre halitose et parodontite et (2) d'analyser les tests d'halitose actueles et de discuter les régimes de traitement disponibles.

\section{References}

Armitage, G. C. (1996) Periodontal diseases: diagnosis. Annals of Periodontology 1, 37215.

Berg, M., Burrill, D. Y. \& Fosdik, L. S. (1946) Chemical studies in periodontal disease (III). Putrefaction of salivary proteins. Journal of Dental Research 25, 231246.

Berg, M., Burrill, D. Y. \& Fosdik, L. S. (1947) Chemical studies in periodontal disease. IV. Putrefaction rates as index of periodontal disease. Journal of Dental Research 26, 67-71.

Bosy, A. (1997) Oral malodor: philosophical and practical aspects. Journal of the Canadian Dental Association 63, 196-201.

Bosy, A., Kulkarni, G. V., Rosenberg, M. \& McCulloch, C. A. G. (1994) Relationship of oral malodor to periodontitis: evidence of independence in discrete subpopulations. Journal of Periodontology 65, 37-46.

Claesson, R., Granlund-Edstedt, M., Persson, S. \& Carlsson, J. (1989) Activity of polymorphonuclear leukocytes in the presence of sulfide. Infection and Immunity 57, 2776-2781.

Coil, J. M. \& Tonzetich, J. (1992) Characterization of volatile sulphur compounds production at individual gingival crevicular sites in humans. Journal of Clinical Dentistry 3, 97-103.

De Boever, E. H. \& Loesche, W. J. (1995) Assessing the contribution of anaerobic microflora of the tongue to oral malodor. Journal of the American Dental Association 126, 1384-1393.

Delanghe, G., Ghyselen, J., Van Steenberghe, D. \& Feenstra, L. (1997) Multidisciplinary breath-odour clinic. Lancet 350, 187.

Delanghe, G., Ghyselen, J., Bollen, C., van Steenberghe, D., Vandekerckhove, N. A. \& Feenstra, L. (1999) An inventory of patient's response to treatment at a multidisciplinary breath odor clinic. Quintessence International 30, 3-7-310.

Fine, D. H. \& Mandel, I. D. (1986) Indicators of periodontal disease activity: an evaluation. Journal of Clinical Periodontology 13, 533-546.

Goldberg, S., Kozlovsky, A., Gordon, D., Gelernter, I., Sintov, A. \& Rosenberg, M. (1994) Cadaverine as a putative compo- nent of oral malodor. Journal of Dental Research 73, 1168-1172.

Goldberg, S., Cardash, H., Browning, H. III, Sahly, H. \& Rosenberg, M. (1997) Isolation of Enterobacteriaceae from the mouth and potential association with malodor. Journal of Dental Research 76, 1770 1775 .

Granlund-Edstedt, M., Johansson, E., Claesson, R. \& Carlsson, J. (1991) Effect of sulfide ions on complement factor C3. Infection and Immunity 59, 696-699.

Hawkins, C. (1987) Real and imaginary halitosis. British Medical Journal 294, 200 201.

Hine, M. K. (1957) Halitosis. Journal of the American Dental Association 55, 37-46.

Iwakura, M., Yasuno, Y., Shimura, M. \& Sakamoto, S. (1994) Clinical characteristics of halitosis: differences in two patient groups with primary and secondary complaints of halitosis. Journal of Dental Research 73, 1568-1574.

Johnson, P. W., Ng, W. \& Tonzetich, J. (1992a) Modulation of human gingival fibroblast cell metabolism by methyl mercaptan. Journal of Periodontal Research 27, 476-483.

Johnson, P. W., Yaegaki, K. \& Tonzetich, J. (1992b) Effect of volatile thiol compounds on protein metabolism by human gingival fibroblasts. Journal of Periodontal Research 27, 553-561.

Johnson, P., Yaegaki, K. \& Tonzetich, J. (1996) Effect of methyl mercaptan on synthesis and degradation of collagen Journal of Periodontal Research 31, 323329.

Kleinberg, I. \& Westbay, G. (1990) Oral Malodor. Critical Reviews in Oral Biology \& Medicine 1, 247-259.

Kleinberg, I. \& Codipilly, M. (1995) The biological basis of oral malodor formation. In: Bad breath: research perspectives, eds. Rosenberg, M., pp. 13-39. Tel Aviv: Ramot Publishing.

Kleinberg, I., Codipilly, D. P. M. \& Globerman, D. Y. (1996) Oxygen depletion by the oral microbiota and its role in oral malodour formation. In: $\mathrm{Bad}$ Breath: a multidisciplinary approach, eds. Van Steenberghe, D. \& Rosenberg, M., pp. 95-109. Leuven: Leuven University Press.

Kostelc, J. G., Preti, G., Zelson, P. R., Stoller, N. H. \& Tonzetich, J. (1980) Salivary volatiles as indicators of periodontitis Journal of Periodontal Research 15, 185 192.

Kostelc, J. G., Preti, G., Zelson, P. R., Brauner, L. \& Baehni, P. (1984) Oral odors in early experimental gingivitis. Journal of Periodontal Research 19, 303-312.

Kozlovsky, A., Gordon, D., Gelernter, I., Loesche, W. J. \& Rosenberg, M. (1994) Correlation between the BANA test and oral malodor parameters. Journal of Dental Research 73, 1036-1042.

Kozlovsky, A., Goldberg, S., Natour, I., Rogatky-Gat, A., Gelernter, I. \& Rosenberg, M. (1996) Efficacy of a 2-phase oil: water mouthrinse in controlling oral malodor, gingivitis, and plaque. Journal of Periodontology 67, 577-582.

Loesche, W. J. \& De Boever, E. H. (1995) Strategies to identify the main microbial contributors to oral malodor. In: $\mathrm{Bad}$ breath: research perspectives, eds. Rosenberg, M., pp. 41-69. Tel Aviv: Ramot Publishing.

Loesche, W. J., Bretz, W. A., Kerschensteiner, D., Stoll, J., Socransky, S. S., Hujoel, P. \& Lopatin, D. E. (1990) Development of a diagnostic test for anaerobic periodontal infections based on plaque hydrolysis of benzoyl-DL-arginine-naphthylamide. Journal of Clinical Microbiology 28, 15511559.

Loesche, W. J., Lopatin, D. E., Giordano, J., Alcoforado, G. \& Hujoel, P. (1992) Comparison of the benzoyl-DL-arginine-naphthylamide (BANA) test, DNA probes, and immunological reagents for ability to detect anaerobic periodontal infections due to Porphyromonas gingivalis, Treponema denticola, and Bacteroides forsythus. Journal of Clinical Microbiology 30, 427433.

Loesche, W. J., Kazor, C. E., Taylor, G. W. (1997) The optimization of the BANA test as a screening instrument for gingivitis among subjects seeking dental treatment. J Clinical Periodontotlogy 24, 718-726.

Mandel, I. D. (1966) Dental plaque: nature, formation and effects. Journal of Periodontology 37, 357-367.

McNamara, T. F., Alexander, J. F. \& Lee, M (1972) The role of microorganisms in the production of oral malodor. Oral Surgery, Oral Medicine, and Oral Pathology 34, 4148.

Messadi, D. V. (1997) Oral and nonoral sources of halitosis. Journal of the California Dental Association 25, 127-131.

Miyazaki, H., Sakao, S., Katoh, Y. \& Takehara, T. (1995a) Oral malodor in the general population of Japan. In: Bad breath: research perspectives, eds. Rosenberg, M., pp. 119-136. Tel Aviv: Ramot Publishing.

Miyazaki, H., Sakao, S., Katoh, Y. \& Takehara, T. (1995b) Correlation between volatile sulphur compounds and certain oral health measurements in the general population. Journal of Periodontology 66, 679684.

Morita, M. \& Wang, M.-L. (2001a) Relationship of sulcular sulfide level of severity of periodontal disease and BANA test. Journal of Periodontology 72, 74-78.

Morita, M. \& Wang, M.-L. (2001b) Relationship of sulcular sulfide level and oral malodor in subjects with periodontal disease. Journal of Periodontology 72, 79-84.

Morris, P. P. \& Read, R. R. (1949) Halitosis: variations in mouth and total breath odor intensity resulting from prophylaxis and antisepsis. Journal of Dental Research 28 , 324-333.

Newman, M. G. (1996) The role of periodontitis in oral malodour:clinical perspectives. In: Bad breath: a multidisci- 
plinary approach, eds. Van Steenberghe, D. \& Rosenberg, M., pp. 3-14. Leuven: Leuven University Press.

Ng, W. \& Tonzetich, J. (1984) Effect of hydrogen sulfide and methyl mercaptan on the permeability of oral mucosa. Journal of Dental Research 63, 994-997.

Niles, H. P. \& Gaffar, A. (1995) Advances in mouth odor research. In: Bad breath: research perspectives, eds. Rosenberg, M., pp. 55-69. Tel Aviv: Ramot Publishing.

Offenbacher, S. (1996) Periodontal diseases: pathogenesis. Annals of Periodontology $\mathbf{1}$, 821-878.

Persson, S., Edlund, M. B., Claesson, R. \& Carlsson, J. (1990) The formation of hydrogen sulfide and methyl mercaptan by oral bacteria. Oral Microbiology and Immunology 5, 195-201.

Pianotti, R., Lachette, S. \& Dills, S. (1986) Desulfuration of cysteine and methionine by Fusobacterium nucleatum. Journal of Dental Research 65, 913-917.

Quirynen, M., Mongardini, C. \& Van Steenberghe, D. (1998) The effect of a 1-stage full-mouth disinfection on oral malodor and microbial colonization of the tongue in periodontitis patients. A pilot study. Journal of Periodontology 69, 374-382.

Ratcliff, P. A. \& Johnson, P. W. (1999) The relationship between oral malodor, gingivitis, and periodontitis. A review. Journal of Periodontology 70, 485-489.

Ratkay, L. G., Waterfield, J. D. \& Tonzetich, J. (1995) Stimulation of enzyme and cytokine production by methyl mercaptan in human gingival fibroblast and monocyte cell cultures. Archives of Oral Biology 40, 337-344.

Rizzo, A. A. (1967) The possible role of hydrogen sulfide in human periodontal disease. I. Hydrogen sulfide production in periodontal pockets. Periodontics 5, 233236.

Rizzo, A. A. (1970) Histologic and immunologic evaluation of antigen penetration into oral tissues after topical application. Journal of Periodontology 41, 210-213.

Rosenberg, M. (1996) Clinical assessment of bad breath: current concepts. Journal of the American Dental Association 127, 475482.

Rosenberg, M. \& McCulloch, C. A. G. (1992) Measurement of oral malodor: current methods and future prospects. Journal of Periodontology 63, 776-782.

Rosenberg, M. \& Leib, E. (1995) Experiences of an Israeli malodor clinic. In: $\mathrm{Bad}$ breath: research perspectives, eds. Rosenberg, M., pp. 137-148. Tel Aviv: Ramot Publishing.
Rosenberg, M., Kulkarni, G. V., Bosy, A. \& McCulloch, C. A. G. (1991a) Reproducibility and sensitivity of oral malodor measurements with a portable sulfide monitor. Journal of Dental Research 70, 1436-1440.

Rosenberg, M., Septon, I., Eli, I., Bar-Ness, R., Gelernter, I., Brenner, S. \& Gabbay, J. (1991b) Halitosis measurement by an industrial sulfide monitor. Journal of Periodontology 62, 487-489.

Rosenberg, M., Kozlovsky, A., Gelernter, I., Cherniak, O., Gabbay, J., Baht, R. \& Eli, I. (1995) Self-estimation of oral maldor. Journal of Dental Research 74, 1577-1582.

Scully, C., Porter, S. \& Greenman, J. (1994) What to do about halitosis. British Medical Journal 308, 217-218.

Shimura, M., Yasuno, Y., Iwakura, M., Shimada, Y., Sakai, S., Suzuki, K. \& Sakamoto, S. (1996) A new monitor with a zincoxide thin film semiconductor sensor for the measurement of volatile sulfur compounds in mouth air. Journal of Periodontology 67, 396-402.

Slots, J. (1977) The predominant cultivable microflora of advanced periodontitis. Scandinavian Journal of Dental Research 85, 114-121.

Socransky, S. S., Haffajee, A. D., Goodson, J. M. \& Lindhe, J. (1984) New concepts of destructive periodontal disease. Journal of Clinical Periodontology 11, 21-32.

Solis-Gaffar, M. C., Niles, H. P., Rainieri, W. C. \& Kestenbaum, R. C. (1975) Instrumental evaluation of mouth odor in a human clinical study. Journal of Dental Research 54, 351-357.

Solis-Gaffar, M. C., Rustogi, K. N. \& Gaffar, A. (1980) Hydrogen sulfide production from gingival crevicular fluid. Journal of Periodontology 51, 603-606.

Sulser, G. F., Brening, R. H. \& Fosdik, L. S. (1939) Some conditions that effect the odor concentration of breath. Journal of Dental Research 18, 355-359.

Tessier, J. F. \& Kulkarni, G. V. (1991) Bad breath: etiology, diagnosis and treatment Oral Health 81, 19-22.

Tonzetich, J. (1971) Direct gas chromatographic analysis of sulphur compounds in mouth air in man. Archives of Oral Biology 16, 587-597.

Tonzetich, J. (1977) Production and origin of oral malodor: a review of mechanisms and methods of analysis. Journal of Periodontology 48, 13-20.

Tonzetich, J. (1978) Oral malodour: an indicator of health status and oral cleanliness. International Dental Journal 28, 309-319.

Tonzetich, J. \& Richter, V. J. (1964) Evaluation of volatile odoriferous components of saliva. Archives of Oral Biology 9, 3945

Tonzetich, J. \& Kestenbaum, R. C. (1969) Odor production by human salivary fractions and plaque. Archives of Oral Biology 14, 815-827.

Tonzetich, J. \& Ng, S. K. (1976) Reduction of malodor by oral cleansing procedures. Oral Surg Oral Med Oral Pathol 42, 172 181.

Tonzetich, J. \& Johnson, P. W. (1977) Chemical analysis of thiol, disulfide and total sulphur content of human saliva. Archives of Oral Biology 22, 125-131.

Tonzetich, J. \& McBride, B. C. (1981) Characterization of volatile sulphur production by pathogenic and non-pathogenic strains of oral Bacteroides. Archives of Oral Biology 26, 963-969.

Tonzetich, J., Coil, J. M. \& Ng, W. (1991) Gas chromatographic method for trapping and detection of volatile organic compounds from human mouth air. Journal of Clinical Dentistry 2, 79-82.

Van Steenberghe, D. (1997) Breath malodor. Current Opinion in Periodontology 4, 137 143.

Van Winkelhoff, A. J., van der Velden, U., Winkel, E. G. \& De Graaff, J. (1986) Black-pigmented Bacteroides and motile organisms on oral mucosal surfaces in individuals with and without periodontal breakdown. Journal of Periodontal Research 21, 434-439.

Yaegaki, K. \& Sanada, K. (1992a) Volatile sulfur compounds in mouth air from clinically healthy subjects and patients with periodontal disease. Journal of Periodontal Research 27, 233-238.

Yaegaki, K. \& Sanada, K. (1992b) Biochemical and clinical factors influencing oral malodor in periodontal patients. Journal of Periodontology 63, 783-789.

Yaegaki, K. \& Sanada, K. (1992c) Effects of a two-phase oil-water mouthwash on halitosis. Clinical Preventive Dentistry 14, 5-9.

Address:

Hom-Lay Wang

Department of Periodontics/Prevention/ Geriatrics

University of Michigan School of Dentistry

1011 North University Avenue

Ann Arbor, Michigan 48109-1078

USA

Fax: 7349360374

e-mail: homlay@umich.edu 